\title{
ODZIV NA »ANKETO O SLOVENŠČINI« PROJEKTA JEZIKOVNA POLITIKA REPUBLIKE SLOVENIJE IN POTREBE UPORABNIKOV
}

Logar, N., Gantar, P., Arhar Holdt, Š., Gorjanc, V., Kosem, I., Krek, S., Stabej, M. (2017): Odziv na »Anketo o slovenščini « projekta Jezikovna politika Republike Slovenije in potrebe uporabnikov. Slovenščina 2.o, 5 (1): 27-37.

DOI: http://dx.doi.org/10.4312/slo2.0.2017.1.27-37.

\section{UVOD}

V začetku letošnjega julija je bilo na forumu SlovLit objavljeno vabilo $\mathrm{k}$ izpolnitvi ankete »o jezikovni rabi, znanju in potrebah jezikovnih uporabnikov v Republiki Sloveniji in uporabnikov slovenskega jezika zunaj nje«. Vabilo sta podpisala Nataša Gliha Komac in Kozma Ahačič, prva kot koordinatorica, drugi kot vodja projekta Jezikovna politika Republike Slovenije in potrebe uporabnikov. Šlo je za enoletni projekt (oktober 2016-september 2017), ki ga je kot vodilni partner izvajal Inštitut za slovenski jezik Frana Ramovša ZRC SAZU v sodelovanju z Akademijo za radio, gledališče, film in televizijo UL, Filozofsko fakulteto UL, Fakulteto za upravo UL, Filozofsko fakulteto UM, Pravno fakulteto UM, Inštitutom za narodnostna vprašanja, Pedagoškim inštitut, Alpineonom, Amebisom ter Zvezo gluhih in naglušnih Slovenije. Projekt sta financirala Ministrstvo za kulturo RS in Javna agencije za raziskovalno dejavnost $\mathrm{RS}$.

Ker gre za zelo pomembno tematiko, ki je neposredno povezana s skorajšnjim iztekom Resolucije o Nacionalnem programu za jezikovno politiko 2014-2018 (ter posledično pripravo nove), in ker dikcija ankete (dalje Anketa o slovenščini) na več mestih zbuja pomisleke o rezultatih, ki jih bo dala, smo se člani ožjega uredniškega odbora revije Slovenščina 2.o skupaj s tukajšnjimi soavtorji odločili za pisni odziv. Opozoriti namreč želimo strokovno javnost in državne ustanove, ki raziskavo financirajo, na nekatere metodološko, ideološko 
in vsebinsko problematične dele raziskave, ki prav zaradi svoje empirične »objektivnosti« terjajo utemeljena pojasnila (ter kot taki ne smejo postati vzor nadaljnjim tovrstnim pristopom $\mathrm{v}$ jezikoslovju, še manj pa jih velja tudi $\mathrm{v}$ prihodnje razpisno spodbujati za potrebe jezikovnopolitičnih odločitev).

\section{ANKETA KOT ORODJE}

Anketa se kot orodje za zbiranje podatkov v družboslovju uporablja že od tridesetih let prejšnjega stoletja. $\mathrm{V}$ humanistiki je anketiranja zaradi specifičnega predmeta obravnave nasplošno manj, čeprav je tudi tu $\mathrm{z}$ nastankom spletnih anket raba te metode $\mathrm{v}$ porastu. Največja prednost anketiranja je možnost nagovora velikega števila anketiranih ob hkrati majhnih, z uporabo spleta lahko celo nikakršnih stroških. $\mathrm{Z}$ anketo dobimo podatke, ki jih lahko preštejemo, razdelimo v skupine, narišemo v grafe ipd., skratka: z anketo prakse, poglede, stališča idr. izmerimo. Raziskovalci, ki se lotimo takega merjenja, se moramo ves čas zavedati, da so rezultati tega početja najprej in predvsem posledica vzorca, na katerem smo meritev opravili, in pa merskega instrumenta samega - torej tega, kaj anketa vsebuje, kako to vsebuje in hkrati česa $\mathrm{v}$ njej ni. Ker na tem temelji znanstvenost raziskovalnih ugotovitev, obstajajo številna dela, ki poučujejo, kako se oblikuje dobra anketa. Ta gredo celo v take podrobnosti, kot so: kako dolga (ali raje kratka) naj bodo anketna vprašanja, katerih (manj razumljivih) besede naj raje ne vsebujejo, kakšno naj bo zaporedje možnih odgovorov (sploh če jih je veliko) itd. Dobra praksa anketiranja je npr. tudi predhodno testiranje na manjših skupinah.

Jezikovna politika je široko in kompleksno področje. Teme, kot so bile identificirane v vabilu Ankete o slovenščini, se dotikajo njenega precejšnjega dela, zato so si sodelujoči v projektu Jezikovna politika Republike Slovenije in potrebe uporabnikov zastavili zahtevno nalogo - namreč, anketno preveriti nekaj, kar je - če hočemo priti do tehtnih tešitev - lahko (oz. bi moralo biti) v resnici predmet širokih debatnih ter različnih javnoforumskih izmenjav in usklajevanj mnenj ter argumentov. Če pa se taka vsebina že meri z anketo, 
potem je pri oblikovanju njenih vprašanj ter vnaprejšnjih možnih odgovorov nujno dvoje: podrobna razdelanost vsake teme in dikcijska pretanjenost. Žal je v obravnavani anketi obojega veliko premalo.

\section{ANKETA O SLOVENŠC̆INI ALI KAKO SE V ANKETI NE SPRAŠUJE}

V celoti bomo navedli in komentirali le štiri sporna anketna vprašanja, čeprav bi bilo mogoče problematizirati tudi več drugih. ${ }^{1}$ Ta štiri vprašanja izkazujejo jasno težnjo vodilnega projektnega partnerja po nadaljnji ohranitvi monopolnega položaja pri pripravi prihodnjih jezikovnih (zlasti normativnih) virov za slovenščino. Menimo, da je bila s to vsebino anketa kot merski instrument znanstvenega raziskovanja zlorabljena.

\section{Potrjevanje določenega jezikovnega nazora in $z$ njim povezane jezikovnopolitične vloge določene ustanove}

\section{2}

Približno na sredini ankete3 so podane naslednje trditve, pri katerih anketirani označi strinjanje na tristopenjski lestvici se ne strinjam - se delno strinjam se strinjam:

(a) Slovenski knjižni jezik ima narodnoidentifikacijsko, (družbeno-kulturno) povezovalno in predstavitveno vlogo.

(b) Priročnike slovenskega jezika z normativnim značajem, npr. slovar knjižnega jezika, pravopis, pravorečje idr., naj potrjuje Slovenska akademija znanosti in umetnosti.

1 Pri tem smo se omejili na anketni profil, ki ga je najbrž izbralo največ anketirancev, tj. najbolje poznam slovenski jezik in druge jezike $v$ Sloveniji (ne pa v sosednjih državah ali po svetu). Anketa ima tu sicer več podprofilov: z rabo jezika se srečujem, ukvarjam profesionalno oz. $\mathbf{v}$ okviru izobraževanja, in sicer s področij (navajamo v nekoliko skrajšani obliki): predšolsko izbraževanje; osnovno- in srednješolsko izobraževanje; znanost in visoko šolstvo; film in gledališče; literatura, glasba, likovna umetnost in umetnostna zgodovina; mediji; prevajanje in tolmačenje, ali neprofesionalno, vendar pa so bila vprašanja, ki jih bomo obravnavali v nadaljevanju, postavljena vsem tem.

2 Ne gre za prvo anketno vprašanje, številčenje smo dodali zaradi preglednosti tukajšnjega prispevka.

3 Ker je, kot smo že opozorili, za Anketo o slovenščini značilno podrobno profiliranje vzorca, je splošen obseg sicer težko določiti. 
(c) Jezikovni uporabniki v Republiki Sloveniji se lahko učinkovito sporazumevamo in se tako dejavno vključujemo v družbeno življenje.

(č) Javne prireditve na ozemlju Republike Slovenije naj bodo vedno tudi v slovenskem jeziku.

(d) Slovenska jezikovna krajina naj se kaže tudi v rabi slovenskega jezika pri poimenovanju različnih ustanov, trgovin, lokalov, javnih napisih ipd.

(e) Tujejezični direktor slovenskega podjetja ali tujejezični lastnik podjetja, ki se ne ukvarja s posredovanjem jezikovnih znanj in ne posluje zgolj v tujini oz. s tujino, sme od svojih zaposlenih na delovnem mestu na ozemlju Republike Slovenije pričakovati in zahtevati sporazumevanje samo v tujem jeziku.

Trditve odpirajo vrsto vprašanj. Npr. kako prvo trditev, ki je teoretsko zahtevna, predvsem pa vezana na razumevanje knjižnega jezika v skladu s Praškim lingvističnim krožkom, anketirani, ki ni jezikoslovec, sploh razume, ali kdo je npr. »jezikovni uporabnik« v tretji trditvi - kaj pa če je njegov prvi jezik albanščina ali kitajščina, ali se potem »učinkovito« sporazumeva v svojem prvem jeziku ali v angleščini (je mar mišljeno v slovenščini?) in kako naj se (ne) strinja s tem, da se »dejavno vključuje v družbeno življenje « - ker: kaj pa to sploh pomeni?; dalje: ali anketirani, preden se strinja s trditvijo (č), sploh pomisli na to, kakšne vse so javne prireditve: ulična gledališča, rock koncerti, mednarodne razstave itd., ki bi vse morale vedno biti tudi v slovenskem jeziku? In kaj pomeni »tujejezični direktor « - direktor, ki govori tuje jezike? Ne, seveda ne, to je tujec, ki ne zna slovensko. Kaj pa če je ravnokar prevzel direktorsko funkcijo in se slovensko še ni utegnil naučiti? Ali sme pričakovati, da bodo npr. prvi trije sestanki s sodelavci potekali $\mathrm{v}$ vsem razumljivem jeziku, ki ni slovenščina? -- Lahko bi nadaljevali, a veliko bolj pomembno kot podvprašanja $\mathrm{k}$ vsaki od zgornjih trditev je naslednje: kaj te trditve $\mathrm{v}$ taki raziskavi sploh počnejo? Jih $\mathrm{v}$ slovenskem prostoru nismo vsaj v času pred zadnjo resolucijo o nacionalnem programu za jezikovno politiko bodisi presegli, bodisi kot konservativne in ideološko obremenjene strokovno ovrgli, bodisi vsaj prepoznali kot preveč poenostavljene ter nedopustno posplošujoče? Način, na kakršnega so zbrane tu, kaže eno samo željo: željo po potrditvi ideologije enojezičnosti in enokulturnosti slovenske države, $v$ kateri se v javnem prostoru 
piše ter govori le knjižna slovenščina, kot jo bo kultivirala Slovenska akademija znanosti in umetnosti. Seveda je mogoče reči, da imajo anketirani pač možnost nasprotovanja,4 a kot rečeno: ker trditve odpirajo toliko relevantnih podvprašanj, je razmišljujočemu respondentu še najlažje, če vprašanje kar preskoči (in s tem prepusti »zmago « v anketnih odgovorih tistim, ki čez trditve nepoglobljeno pohitijo). Ali če se navežemo na prejšnje poglavje: vsaka od teh trditev je lahko izhodišče za razpravo. Razpravo omogočajo druge raziskovalne metode, anketna pač ne. Raziskovalci, ki so te trditve zapisali v anketo, bi to morali vedeti.

\section{Potrjevanje največje pogostosti uporabe jezikovnih virov določene ustanove}

Približno v drugi polovici ankete sta navedeni naslednji dve vprašanji:

\section{2.}

Kako pogosto uporabljate naslednje priročnike? /lestvica: ne poznam - nikoli - enkrat ali nekajkrat na leto - enkrat ali nekajkrat na mesec - enkrat ali nekajkrat na teden - enkrat ali nekajkrat na dan/

Slovar slovenskega knjižnega jezika

Slovenski pravopis

Slovenska slovnica

terminološki slovarji za različna strokovna področja, npr. (prosimo, napišite):

slovarji tujk

Slovar slovenskih frazemov

Simonimni slovar slovenskega jezika

slovenski etimološki slovarji

$4 \mathrm{Ni}$ zanemarljivo, da so odgovori oblikovani tako, da sta za strinjanje s trditvami ponujeni dve možnosti (se strinjam in se delno strinjam), za nestrinjanje pa samo ena, povsem absolutna (se ne strinjam). Čeprav delno strinjanje seveda implicira tudi delno nestrinjanje, ima tovrstna formulacija na anketirance lahko vpliv. Vsekakor pa med možnimi odgovori manjka ne vem oz. ne morem oceniti. 
dvojezični slovarji

Slovenski lingvistični atlas

narečni slovarji

drugo (prosimo, zapišite):

In vprašanje:

\section{3.}

Kako pogosto uporabljate naštete vire in orodja? /lestvica je enaka kot pri 2/

Fran

Termania

Terminologišče

Evroterm

Pedagoški slovnični portal

Jezikovna Slovenija

korpus Gigafida

korpus Gos

korpus Janes

korpus Kres

korpus Lektor

korpus Nova beseda

korpus Šolar

Jezikovna svetovalnica Inštituta za slovenski jezik Frana Ramovša ZRC SAZU

Terminološka svetovalnica Inštituta za slovenski jezik Frana Ramovša ZRC SAZU

črkovalnik v urejevalniku besedil

avtomatski slovnični pregledovalnik

konkordančnik NoSketchEngine

orodje za samodejno prepoznavanje govora 
orodje za samodejno prepoznavanje govorcev

orodje za sintezo govora

strojni prevajalnik

drugo (prosimo, navedite):

Vprašanje 2 samo po sebi ni sporno. Lahko ugotovimo, da so se raziskovalci vodilnega projektnega partnerja pač odločili, da preverijo pogostost rabe priročnikov, ki so jih izdali sami (pretežno so namreč na seznamu taki). Več raziskav sicer opozarja, da so odgovori na vprašanje o pogostosti rabe jezikovnih virov, kot je bilo zastavljeno v Anketi o slovenščini, lahko sporni, saj so subjektivni in pogosto spodbujeni z željo anketiranega po ugajanju. Težava pa bi lahko bila še v tem, da lahko seznam v kontekstu drugih tu izpostavljenih vprašanj izzveni bolj kot prikaz vsega »njihovega « - in ker je nabor kar obsežen, je le še korak stran tudi sklep: »vse, kar obstaja, je njihovo« (a vse to bi lahko bil, kot rečeno, nehoten vtis - vprašanje lahko razumemo tudi kot nesporno). Čisto drugačen pa je nabor - kar 21 - virov in orodij pri naslednjem vprašanju (3). Njegova problematičnost niti ni toliko $\mathrm{v}$ tem, da gre za anketno nadpovprečno dolg seznam (za katerega je v osnovni metodološki literaturi priporočeno krajšanje, skupinjenje ali pa vsaj nestatičnost, torej to, da se zaporedje (v tem primeru) virov in orodij z vsako anketo samodejno spreminja), temveč v tem, da daje vtis enorodnosti (po vsebini, namenu, načrtovanih uporabnikih itd.), ki pa nikakor ni resnična. To anketno vprašanje bi se lahko interpretiralo v smislu enačenja redke rabe/nepoznavanja z nepomembnostjo (v smislu: širše nerabljenosti in torej neuporabnosti) virov, kakršni so npr. korpus Lektor, konkordančnik NoSketchEngine ali orodja za sintezo govora. Pri tovrstnih gre za specializirane vire in orodja, ki so nujni za slovenščino, njihova raba pa je seveda vezana na jezikoslovce ali celo le ozek krog raziskovalcev, zato jih ne gre primerjati s Franom ali Termanio (ki sta poleg tega tudi zbirni mesti za množico virov). Opozarjamo torej, da táko enačenje (in torej merjenje kot med seboj enakih) odpira prostor za manipulativno interpretacijo. 


\section{Potrjevanje jezikov(slov)ne avtoritete določenega ustanove}

Takoj za zgornjima je v anketo vključeno vprašanje, ki zelo spominja na trditev (b) iz vprašanja, ki smo ga na začetku tega poglavja označili z 1, čeprav je zakrito v obliko ugotavljanja stanja.

\section{4 .}

Katera ustanova oz. ustanove pripravljajo priročnike slovenskega knjižnega jezika z normativnim značajem, npr. slovar knjižnega jezika, pravopis, pravorečje itd.? /Možnih je bilo več odgovorov./

(a) Inštitut za slovenski jezik Frana Ramovša ZRC SAZU, univerze itd. pod okriljem Slovenske akademije znanosti in umetnosti

(b) univerze

(c) državni organi (vlada, ministrstva, državni zbor)

(č) drugo (prosimo, navedite):

(d) ne vem

Anketirani, ki je vsaj do obsega osnovne šole razgledan po priročnikih za slovenščino, bo kot odgovor tu res težko izbral karkoli drugega kot (a), zlasti ker so tudi univerze priključene $\mathrm{k}$ tej točki (imajo pa sicer tudi ločeno mesto $\mathrm{v}$ drugem možnem odgovoru). Poleg tega se odgovor (a) ponuja kot "pravilen« tudi zato, ker je prvi na seznamu, ker izstopa po dolžini, obenem pa je inštitut $\mathrm{v}$ celem naboru odgovorov edina natančno poimenovana ustanova - pri ostalih gre za generična poimenovanja, kar sugerira organizacijsko nejasnost in nespecifičnost. Odgovor (c) je v resnici podcenjujoč: ali so raziskovalci, ki so pripravili anketo, resno mislili, da obstajajo osebe, ki so pripravljene 20 minut odgovarjati na precej zahtevna vprašanja o slovenski jezikovni politiki in ki obenem mislijo, da novi SSKJ pripravlja 5 - vlada? Pravzaprav se celotno vprašanje zdi nepotrebno, kajti podatke, kdo izdaja različne priročnike normativnega značaja, morajo raziskovalci, ki so vodili projekt, pač poznati sami (in jih seveda tudi poznajo) - le zakaj bi o tem spraševali anketirane?

5 Ne pa potrjuje, kar sicer ponekod v tujini velja. 
Razen če je izrecna želja sestavljavcev ankete ugotoviti naslednje: bodisi (1.) kolikšna je pri anketiranih nevednost o pripravljalcih priročnikov (kar je malo verjetno; pa tudi če bi se taka nevednost potrdila, komu mar, verjetno je bolj pomembno, da poznajo in upoštevajo vsebino priročnikov) bodisi (2.) ponovno dobiti potrditev trditve (b) iz že izpostavljenega anketnega vprašanja 1. In ta potrditev se tu - prav mogoče je, da tudi na podlagi vtisa, ki lahko nastane pri neposredno predhodnih vprašanjih 2 in 3 - gotovo »zgodi«.

\section{ANKETA O SLOVENŠČINI ALI KAKO SE NE ZBIRA PODATKOV ZA PRIHODNJE JEZIKOVNOPOLITIČNE NAČRTE}

Na tej točki se morda zdi, da smo se odzvali pikolovsko, zgolj na nekaj vprašanj v sicer obsežni anketi. Nismo, presodili smo vsa vprašanja, kolikor so nam bila javno dostopna $\mathrm{v}$ času odprtosti ankete. Čeprav je že zloraba ankete kot empirične metode raziskovanja za ohranjanje lastne vodilne vloge pri konceptualizaciji in uresničevanju pomembnega dela jezikovne politike $\mathrm{v}$ Sloveniji s strani Inštituta za slovenski jezik Frana Ramovša ZRC SAZU, ki jo kažejo tu izpostavljeni deli ankete, problematična ter odpira vprašanje verodostojnosti celotne raziskave, je v Anketi o slovenščini v profilu in njegovih podprofilih, ki smo si jih natančneje ogledali (gl. op. 1), še več vprašanj bodisi terminološko nejasnih, vsebinsko dvoumnih in nenatančnih, samoumevnih, parcialnih ali pa prezapletenih, da bi bilo nanje mogoče odgovoriti na kratko ali z nekajstopenjsko lestvico. ${ }^{6}$ Marsikje so vnaprej dani odgovori, ki prikazujejo idealizirano in ne realno, tj. močno raznoliko jezikovno rabo - in s temi idealiziranimi odgovori se je vsekakor mogoče na hitro (kakor se pač rešuje anketa) strinjati. Ravno to je tudi razlog, da se jih ne postavlja v anketi. S tem se namreč ustvarja prostor za potrjevanje ideoloških predpostavk, ki temeljijo na naučenih, hipotetičnih, ljubiteljskih ali populističnih predstavah o jeziku in če na čem, potem jezikovnih načrtov na teh gotovo ne gre graditi.

6 Možnost vnosa obširnejšega mnenja je sicer v anketi pogosta, vendar pa se je treba zavedati, da jo anketirani nasplošno v celotnem obsegu ankete in v velikem številu redko izkoristijo, sploh če je nabor vprašanj tako dolg. 
Zaradi navedenega pozivamo odgovorne, da celotno anketo objavijo in s tem omogočijo, da oceno vseh njenih delov podajo še drugi zainteresirani ter da na podlagi natančno predstavljenega vzorca podajo lastne interpretacije. Iz povzetka projekta7 je namreč jasno, da bo Ministrstvo za kulturo RS kot glavni pripravljalec nove resolucije o nacionalnem programu za jezikovno politiko rezultate ankete razumelo kot trdno podlago za pripravo prihodnjega tovrstnega dokumenta:

Raziskovalni projekt neposredno odgovarja na potrebe pripravljalcev strateških dokumentov, predvsem Resolucije o nacionalnem programu za jezikovno politiko in iz nje izhajajočih akcijskih načrtov, da bi dobili celovito in empirično podprto raziskavo temeljnih sociolingvističnih problemov. Prinaša namreč celovit pregled sociolingvistične situacije v RS ter opis jezikovnih potreb uporabnikov v RS in potreb uporabnikov slovenskega jezika zunaj nje z namenom oblikovanja izhodišč za novi nacionalni program za jezikovno politiko.

Obenem pozivamo politične odločevalce, da vzpostavijo okolje, v katerem bi bili vsi kot jezikovna skupnost dejansko zainteresirani za poznavanje realnega stanja, saj smo prepričani, da je le na podlagi poznavanja dejanskih jezikovnih problemov, dobrih praks in uspešnih konsenzualnih rešitev mogoče oblikovati premišljene in učinkovite postopke ter strategije, $\mathrm{s}$ katerimi bomo utrjevali in usmerjali jezikovno prihodnost Republike Slovenije.

7 Projekt Jezikovna politika Republike Slovenije in potrebe uporabnikov, povzetek (prvi odstavek), www.sicris.si. 
To delo je ponujeno pod licenco Creative Commons: Priznanje avtorstvaDeljenje pod enakimi pogoji 4.o Mednarodna.

This work is licensed under the Creative Commons Attribution-ShareAlike 4.0 International.

https://creativecommons.org/licenses/by-sa/4.o/

(C) (1) () 